\title{
The Psychological Effect of Political and Social Injustice on the Individual in William Godwin's Caleb Williams
}

\author{
Sumaya M. Alhaj Mohammad ${ }^{1}$ \\ ${ }^{1}$ The Department of English Language and Literature, Zarqa University, Zarqa, Jordan \\ Correspondence: Sumaya M. Alhaj Mohammad, The Department of English Language and Literature, Zarqa \\ University, Zarqa, Jordan. E-mail: sumaya2003@hotmail.com
}

Received: August 5, $2017 \quad$ Accepted: August 22, $2017 \quad$ Online Published: August 30, 2017
doi:10.5539/ells.v7n3p48
URL: http://doi.org/10.5539/ells.v7n3p48

\begin{abstract}
This study aims at exploring William Godwin's Things as They Are; or The Adventures of Caleb Williams (1794) as a social and political novel that sheds light on the psychology of the eighteenth-century English individual. It discusses the dangers of injustice and proves that bad laws can be destructive in the sense that they cause people to live unstably as they suffer from psychological disorders, such as paranoia. The study refers to some political and social facts of the eighteenth-century, to contextualize the suffering of the individual. It emphasizes that the manipulation of laws creates an unbalanced social life; and thus, it leads to psychological instability. The study, then, connects Foucault's ideas of surveillance to reveal how tyranny is evil for both the dominant and the dominated who live miserably. This dichotomy is investigated in the study mainly through the characters of Falkland, the murderer and Caleb Williams, the protagonist who searches for the truth.
\end{abstract}

Keywords: Caleb Williams, William Godwin, social injustice, Foucault

\section{Introduction}

William Godwin's Things as They Are; or The Adventures of Caleb Williams (1794) is one of the significant novels in the eighteenth century, as it sheds light on vital issues that were rarely discussed in literature at that time. Besides being a social novel that probes deep into the vices of the English society in the Augustan Era, Caleb Williams is considered revolutionary because it boldly questions the political and social justice in England at that time. The novel, moreover, instigates the poor to question the authority of the aristocrats. It bluntly aims at spreading awareness about people's rights to undermine the illegal and tyrannical dominance of the aristocrats over the general populace. Godwin's bildungsroman investigates issues concerning human rights in the eighteenth century through tracing the suffering of the protagonist Caleb Williams. The narrative reveals how totalitarianism and governmental surveillance negatively affect the psyche of the individuals, and trap them within identity crises. The first-person mode of narrative of the novel fortifies the emphasis on the individual, and his right of self-expression and self-assertion.

\section{Literature Review}

Several studies have approached Caleb Williams from different perspectives. In his article "Extraordinary and Dangerous Powers': Prisons, Police, and Literature in Godwin's Caleb Williams" (2010), for instance, Quentin Bailey believes that the governmental surveillance, and the miserable state of prisons in the eighteenth century in England are reasons behind the suffering of the individual. Thus, Caleb Williams aims at revealing this harsh reality through Caleb's experience. Whereas Paul Huggins' Identity Crisis: Oppressive Ideologies and Fearing the Loss of the Self in the Work of William Godwin (2007) attempts at portraying to which extent institutions and ideologies in the eighteenth-century England could create fragmented identities and unfulfilled individuals whose voices are suppressed and marginalized. Huggins believes that the dominance of institutions in Caleb Williams produces violence in the society; consequently, the individual suffers a fragmented sense of self-identity.

This research, however, attempts to tackle a different perception of the novel. It is a theoretical and analytical study that aims at offering a psychological reading of Godwin's Caleb Williams, based on the social and political milieu. The study proves that totalitarianism and monopolizing power negatively affect the psyche of individuals, and lead them to suffer from psychological disorders, such as paranoia. The significance of this study is that it 
intertwines the social, political and psychological aspects to portray how laws have a profound negative influence on both the dominant and the dominated groups that hinders individuals from achieving their life-goals and asserting their self-identity. It finally concludes that corrupt and oppressive governments prevent people from thinking freely by silencing their voices, and monitoring them. This, consequently, harms people to the point that they lose their self-esteem, get frustrated, live unstable lives and become violent.

\section{Discussion}

Caleb Williams is a bildungsroman that narrates the story of its protagonist Caleb Williams, a poor orphan who works for a gentleman called Falkland. Though Caleb's master is a quiet and honorable man, his distemper piques Caleb's curiosity; thus, he starts searching for the reason behind his sudden rages. Collins, the administrator of Falkland's estate, tells Caleb the story of Falkland. He explains that Falkland has been a neighbor of a tyrant master whose name is Tyrrel. The two men have been rivals because they are in sharp contrast; while Falkland is noble and righteous, Tyrrel is cruel and callous. The struggle between the two men has ended when Tyrrel is killed, and the Hawkins, a father and a son, are accused of the murder. This narrative, however, has not satisfied Caleb, who feels that Falkland is the real murderer of Tyrrel. Caleb's "inquisitive mind" (Godwin, 1988, p. 185), therefore leads to his downfall because when Falkland realizes that Caleb knows about his murder, he accuses him of robbery and jails him. Caleb suffers in prison and decides to escape; he moves from one place to another and lives with a gang of thieves; nevertheless, Falkland keeps chasing and threatening him. Eventually, Caleb decides to report the murder at any cost though he knows that the court will not listen to a poor like him. Falkland confesses the murder after he is sick to death. Finally, Falkland dies, but Caleb does not feel content because he still sees a bright side in Falkland's personality.

This crime narrative closely belongs to the zeitgeist of the eighteenth century, which is not only the age of reason, science and enlightenment, but also the age of crime mainly due to the growth of population in London. "Britain possessed no effective police force prior to the 19th century." Therefore, "the Bow Street Runners", who "worked part-time and without uniform" was established. Those "thief-takers" were "appointed in 1749" by Henry Fielding to arrest criminals and punish them (Newman, 1997, pp. 69-70). In addition to the unjust decisions of the Bow Street Runners, wealthy people were privileged over the poor, and were empowered by the government. This system created chaos and gave opportunities to tyrants and landowners to gain power and use it over the common people. Such powers did not only create chaos and encourage anarchy, but they also had a profound impact on the psyche of the people who felt confused because they have lost their free-will as they are dominated by the state.

Professor Saintsbury believes that William Godwin is "[t]he first systematic anarchist," as his novel opens up revolutionary ideas (Hindle, 1988, p. 4). Godwin opposes the idea that the "[g]overnment intrudes itself into every rank of society." Thus, he wrote his novel to make "a general review of the modes of domestic and unrecorded despotism by which man becomes the destroyer of man" (ibid, p. 7). The novel reveals how the aristocrats, who are above the law, try cruelly to destroy the lives of other people to serve their own interests. Caleb complains in the novel that "when two squires lay their heads together, they do not much matter law, you know; or else they twist the law to their own ends" (Godwin, 1988, p. 173). Another incident that proves granting undeserved power to the aristocrats is when Falkland asks Caleb Williams: "do you think you are out of the reach of my power, because a court of justice has acquitted you?" (ibid, p. 204).

Quentin Bailey answers this question based on the context in which Godwin presents his narrative: Bailey asserts that:

The answer, of course, is "no," and the novel relentlessly demonstrates the pervasiveness of the "mysterious and undefined" power that the state was in the process of constructing in the 1790s in order to ensure its control of the populace. It is, we might say, less about Things As They Are, than things as Godwin imagined they would be once the new "policeman-state" was firmly established. (Bailey, 2010, p. 548)

Bailey, therefore, advocates Godwin's idea that such a "police-state" must be revoked in order to save the country and its citizens. The novel highlights the danger that hovers over the English people through portraying the ambivalence of the law that prefers certain people to others. Sketching the contrastive characters of Falkland and Caleb, for instance, is one way to prove such injustice. In spite of being the real murderer, Falkland is confident because he is sure that he has the impunity that protects him. While Caleb, who is innocent, is afraid all the time; thus, he spends most of his life suffering as an outcast. In this case, morality does not matter for people, as it does not credit them; instead, what grants people privilege one over each other is social position and wealth.

The protagonist's identity crisis is obvious to the reader from the very beginning of the novel. John Locke argues 
that "wherever law ends, tyranny begins" (Locke, 1980, p. 22), and Edmund Burke states in one of his speeches in 1780 that "[b]ad laws are the worst sort of tyranny" (Burke, 1895, p. 318). The chaotic situation in the society of the novel, then, is resulted from the lack of strict laws, or the manipulation of laws in favor of the aristocrats. This confusion leads inevitably to the suffering of the individual. The first-person narrator, Caleb Williams, starts explaining his predicament by saying: "My life has for several years been a theatre of calamity. I have been a mark for the vigilance of tyranny, and I could not escape" (Godwin, 1988, p. 13). The long-suffering of Caleb in the novel and the life-threatening situation in which he lives are unjustified; he is not a criminal or a villain to be punished, but merely a righteous man who aspires to find the truth, by telling what he knows. Caleb says, "No, I will use no daggers! I will unfold a tale! ...The justice of the country shall hear me! ...I will speak with a voice more fearful than thunder!" (ibid, p. 226).

Caleb, in other words, seeks to gain his freedom of expression, and to unveil the truth about Tyrrel's murder. Because Caleb believes that it is his right to think for himself, and it is his duty toward his country to unfold the truth, he decides to do what he believes is true. "I am an Englishman," he says, "and it is the privilege of an Englishman to be sole judge and master of his own actions" (ibid, p. 121). This individualism is what the empiricists of the seventeenth and the eighteenth century, such as Thomas Hobbes, John Locke and David Hume call for. Such thinkers believe that the individuals' opinions are products of their own thinking and empirical experiences, and not imposed by certain authorities or dogmas. This empiricism marks the beginning of identity issues and self-consciousness, which are essential themes in Caleb Williams. Based on this point in particular, the novel is classified as revolutionary; it calls people, who unwillingly find themselves trapped in a master-slave relationship, in which they have to act against the other, to reject the authoritative voices, and to revolt against their so-called "masters."

Instead of emphasizing individualism, the society where injustice is overwhelming creates clashing types. Hatred, revenge and envy, for example, are common feelings among the English gentlemen because of their rivalry relationship. This is obvious in the relationship between Tyrrel and Falkland who compete to be dominant. Both of them are selfish because they seek supremacy. According to Huggins "[ $t]$ hese systems of oppression are so embedded in British society that they are considered "reality,"” so that the lower class people believe that they are inferior to the aristocrats (Huggins, 2007, p. 7). Not only the feeling of inferiority is dangerous, but also the passive acceptance, which makes people stop asking for their rights. Benjamin Hawkins says in the novel, "I have been used ill enough, God knows. But I bear no malice; my heart is at peace with all mankind; and I forgive every body" (Godwin, 1988, p. 91). It is noticeable that Benjamin's peacefulness does not ameliorate his life; it leads him to the gallows instead. When common people believe in their inferiority, reforming the society becomes a complicated issue. Godwin rejects submission, which makes human-beings each others' enemies. Caleb wonders in the novel: "how many men have been aspersed, and even at sometime or other almost torn to pieces by their fellow-creatures, whom, when properly understood, we find worthy of our reverence and love" (ibid, p. 92).

The clashes among individuals and institutions over authority and good reputation harm low-class people. For example, the struggle between Falkland and Tyrrel leads to the hanging of the Hawkins. Falkland enjoys impunity and good reputation; thus, no one doubts that he might be the murderer. When Caleb does, however, his life is turned into a nightmare because Falkland has the power to threaten or murder him. Falkland jails Caleb, and keeps an eye on him all the time. This kind of surveillance makes Caleb paranoid and anxious all the time. This "authoritative gaze," as Michel Foucault calls it in his book Discipline and Punish (1975), terrorizes people. David Hogsette argues that:

Much of the terror in Caleb Williams indeed stems from a realization that Falkland's authoritative gaze ultimately isolates Caleb from all human community and leads him to despise himself, resulting in self-alienation. Ultimately, though, the true terror in this Gothic novel is self-imposed surveillance and linguistic imprisonment. (Hogsette, 2005, p. 4)

Caleb, thus, ends up miserably because he tries to get over the unjust rules, and to think freely as an independent knowledgeable individual. Through this character, Godwin pays the readers' attention to the importance of validating "human rights", a term introduced to the world in the eighteenth century; the time of the birth of Godwin's novel.

Seemingly, Caleb is aware of his rights as a human being, as he condemns tyranny and totalitarianism. He, for instance, is shocked that Alexander of Macedon is called Alexander the Great, and he suggests that he should, instead, be called "the Great Cut-throat" (Godwin, 1988, p. 87) because of the massacres that he did. Falkland's reaction is at heart of the Foucault's theory of discursive power. Falkland replies to Caleb by saying that: 
The death of a hundred thousand men is at first sight very shocking; but what in reality are a hundred thousand such men, more than a hundred thousand sheep? It is mind, Williams, the generation of knowledge and virtue, that we ought to love. This was the project of Alexander; he set out in a great undertaking to civilise mankind; he delivered the vast continent of Asia from the stupidity and degradation of the Persian monarchy: and, though he was cut off in the midst of his career, we may easily perceive the vast effects of his project (Ibid, p. 88).

This excerpt reveals how Falkland finds it easy to kill people in order to maintain power. Moreover, he tries through his discursive language to justify massacres. He contends that killing people can be a means of civilization, while in fact behind each massacre stands a tyrant hungry for power. This idea is explained by Foucault who argues that institutions, including governments, maintain power through using a certain discourse to persuade people of the need of persecution. He argues that "[a] real subjection is born mechanically from a fictitious relation" (Foucault, 1995, p. 202). When people, thus, feel surveilled, they start to act unconsciously as the prisoner demands, even if the prisoner is not really observing. This has negative consequences in the case of Caleb who starts to feel paranoid all the time.

Foucault's knowledge-power dichotomy reveals how knowledge can be dangerous in the sense that it manipulates the truth in favor of particular groups. In the novel, thus, there is an emphasis on the vitality of reading and gaining knowledge. Caleb is aware of his rights because he is a knowledgeable man who is interested in reading, and particularly reading literature. He, therefore, refuses to be treated as a slave.

The Master-Slave relationship is omnipresent in the novel. It is the reason behind the struggles and the hardships of the characters, whose miseries lead to further inevitable ones; and thus, they are caught in vicious circles of suffering. Falkland's struggle with Tyrrel over dominance in the beginning of his novel causes the former to become a murderer; an act that opposes his good nature. Caleb observes that, "a man of so much principle afterwards deliberately proceed[s] to the very worst of crimes" (Godwin, 1988, p. 93). The psychological suffering of Falkland, on the other hand, causes the suffering of Caleb, as he is the only one who knows the truth, but without being able to change the status quo, since the judges will not listen to a poor man and condemn a rich one.

Psychology is highly important in the novel, and noticeably it develops the plot, and unfolds intrinsic aspects about the characters. Caleb, for instance, discovers Falkland's murder based on some psychological evidence; his temper. After that, he finds the letter of Hawkins that can be a physical proof. The novel traces the state of mind of a murderer, Falkland, who tries to hide his murder, but his countenance reveals his inner dilemma, until he dies out of this burden. In the beginning of the novel, Falkland is portrayed as a gentleman, who is respected by everyone. After the murder, however, his discourse is changed to be tyrannical. He, for instance, curses justice and virtue, "[d]etested be the universe, and the laws that govern it!" he says, "[h]onour, justice, virtue, are all the juggle of knaves! If it were in my power I would instantly crush the whole system into nothing!" (Godwin, 1988, p. 92). Falkland is aggressive because he is afraid; he hates justice because he knows that if justice prevails, he will be punished. After that, he starts to be isolated from people, since he loses his faith in everything, and he becomes desperate. Evidently, injustice is evil for both the privileged and the underprivileged in the society. Falkland, therefore, gets confused and starts to question social values such as justice;

Justice! - he muttered. I do not know what is justice. My case is not within the reach of common remedies; perhaps of none. I only know that I am miserable. I began life with the best intentions and the most fervid philanthropy; and here I am — miserable — miserable beyond expression or endurance. (Ibid, p. 92)

Falkland is overwhelmed with misery though he has been a good person all over his life. He is changed because he is insatiable for power. He eventually ends up a "ghost" -like, a fatigue person who looks like a "corpse" (ibid, p. 229).

Falkland's suffering causes Caleb, who bears the responsibility of knowing the truth of the murder, to suffer silently. Falkland practices his authority over Caleb and he keeps monitoring him until Caleb becomes desperate that he wants only to leave Falkland's service in any way. In the beginning of the novel, Caleb appears as a man of an "inquisitive spirit," and "liberal ambition" (ibid, p. 185). He, first, does not accept Collins' narrative as it is, which shows that he is a free thinker who does not accept one side of the truth as a given. His meticulous eye, and his active mind, thus, enable him to enter Falkland's psyche and uncover his hidden secret. Caleb does not seek power or money; he only cares about telling the truth, and becoming a "master of [his] own actions" (ibid, p. 116). $\mathrm{He}$ feels responsible because he realizes that knowledge is responsibility, so he starts to despise his situation and his society that accepts injustice. He comments: "My resentment was not restricted to my prosecutor, but extended itself to the whole machine of society" (ibid, p. 138). He also criticizes how thieves are herd in prisons for minor crimes, while other tyrants live freely. He reaches a point of despair that makes him completely selfless. 
Consequently, he has to endure the miserable life in prison, and he has to disguise and hide his real identity in order not to be known. He says, "My life was all a lie. I had a counterfeit character to support. I had counterfeit manners to assume" (ibid, p. 186).

Caleb moves in the course of the novel toward self-consciousness, as he decides eventually to tell what he knows, no matter what price he might pay. He goes to the house of the chief magistrate and forces him to listen to his story though he is a poor supposedly voiceless man. Caleb's quest for finding the truth wastes his appearance "to a shadow" (ibid, p. 193). He states that this incident distorts his self-identity, and his value as a human being. He laments his diaspora in the end of the novel, as he say, "Alas! I am the same Caleb Williams that, so short a time ago, boasted that, however great were the calamities I endured, I was still innocent ...I began these memoirs with the idea of vindicating my character. I have now no character that I wish to vindicate" (ibid, p. 234). Caleb is sorrowful and melancholic by the end of his experience although he does what he wishes, and he realizes his putative self-assertion by making his voice heard, especially that his defying of a protected squire like Falkland is a revolutionary action that not any man dares to do. He, however, feels hopeless because he thinks that this incident is not personal; it is rather the concern of everyone in the society. Caleb also knows that such a terrible unjust occurrence is recurrent in his society which lacks the minimum requirements of justice and human rights. He, in other words, ends up "sadder but wiser."

\section{Conclusion}

In conclusion, it is unsurprising that Godwin's Caleb Williams was criticized of causing anarchy in England when it was first published. Godwin wrote his novel during the French revolution; thus, it was a threatening work that could have caused upheavals in England. Godwin's Gothic setting in dark and damp prisons and the cruel events of the novel reveal how he is concerned with highlighting a hidden truth about the English society at that time. His novel carries the seeds of romanticism, as it gives room for the poor to speak, and the spirit of modernity, as it centers the individual and his/her psychological issues The novel bluntly criticizes the usurpation of power, and the unjust laws that privilege a group of people over the other. Godwin warns that such rules create a master-slave relationship among the classes of the society, which leads to psychological disorders for the individual. Godwin proves that tyranny does not only harm the underprivileged people like Caleb, but also the aristocrats who struggle over power. Both Tyrrel and Falkland suffer and die due to their eagerness to dominate. The novel, therefore, implies an urgent call for re-ordering the society, and re-considering the influence of the aristocrats and the misery of the poor.

\section{References}

Bailey, Q. (2010). Extraordinary and dangerous powers': Prisons, Police, and Literature in Godwin's Caleb Williams. Eighteenth-Century Fiction, 22(3), 525-584. https://doi.org/10.1353/ecf.0.0135

Burke, E. (1895). Speech in Bristol Previous to the Elections. The Works of Edmund Burke with a Memoir, 1. New York: George Dearborn Publisher.

Foucault, M. (1995). Discipline and Punish: The Birth of the Prison (Alan Sheridan trans.). New York: Vintage Books.

Godwin, W. (1988). Things as They Are; or, the Adventures of Caleb Williams. In M. Hindle (Ed.). New York: Penguin.

Hindle, M. (1988). Introduction. Things as They Are; or, the Adventures of Caleb Williams. New York: Penguin.

Hogsette, D. S. (2005). Textual Surveillance, Social Codes, and Sublime Voices: The Tyranny of Narrative in Caleb Williams and Wieland. Romanticism on the Net, 38(39). https://doi.org/10.7202/011667ar

Huggins, P. (2007). Identity Crisis: Oppressive Ideologies and Fearing the Loss of the Self in the Work of William Godwin. Southern Illinois University at Carbondale, ProQuest, UMI Dissertations Publishing.

Locke, J. (1980). Two Treatises of Government [1960]. In C. B. McPherson (Ed.). Indianapolis and Cambridge: Hackett Publishing Company.

Newman, G. (1997). Bow Street Runners. Britain in the Hanoverian age, 1714-1837: an encyclopedia (pp. 69-70). London: Taylor \& Francis.

\section{Copyrights}

Copyright for this article is retained by the author, with first publication rights granted to the journal.

This is an open-access article distributed under the terms and conditions of the Creative Commons Attribution license (http://creativecommons.org/licenses/by/4.0/). 